\title{
〈100号記念特集〉
}

\section{2. 炭素研究の想い出ー1940年代一}

\section{赤 松 秀 雄 $^{*}$}

中学の化学で同素体について習いました。その例とし て, ダイヤモンド, 黒鉛, スミ (無定形炭素) が同じ炭素 であることをきいたときの驚きが記憶に残っています。 てのうちスミは最も古くから，人類が火を使うようにな って以来知っていたはずです。その長い歴史のなかで, 人類はスミの特質をたくみに利用しております。最近発 見された太安万呂の墓には多量のカタズミが使用されて いて木炭槨之よばれる構造のものだそうであります。そ れは今から 1200 年位前の墓です。とてろがスミを含ん で無定形炭素というあのが本当に理解されるようになった のは極めて新しいことです。それは 1940 年代から 1950 年代にかけてのてとであります。私はたまたまその時期 に研究生活に入っていたので無定形炭素, 広く一般に炭 素が炭素材料として使われるようになった発展の段階を 自ら経験いたしました。昔話になるかむしれませんが， 私の経験を通して話させて頂きます。それを炭素の多面 性がどこからでてくるかということとつないでみたいと 思います。

炭素の 1 万年余の歴史のなかで, 1940 年代に急速に 無定形炭素の理解が進んだ埋由はいろいろあります。そ の一つはやはり戦争によるあのでしょう。戦争を境とし て技術が急速に発達したととは事実です。たとえば, 力 ーボンブラックについて言えば，それまで地下たびやゴ ム長用のゴムに混ぜていたカーボンブラックでは爆撃機 のタイヤ用には役に立たないのです。そこで研究が必要 となります。電気材料や通信機材料の急激な進歩のなか に炭素材料の役割も少なくありません。あう一つ重要な ととは原子炉用材料であります。原子炉ができてウラ二 ウムにあてる中性子の減速材や反射材として炭素が用い られるようになると従来みなかった高い純度が要求され るととになりました。人造黒鉛は精密科学の対象となる マテリアルとなったわけです。その一方では研究手段の 進歩があります。たとえば電子顕微鏡の出現は炭素研究 にうってつけのものでした。理論的な面としては固体物 理学(物性論)の進歩が炭素研究を刺激しましたし, また 化学の方では分子軌道法による電子状態の研究手段の発 達がみられました。こういうことが1940 年代に一勢に 展開したのであります。

それでは，それ以前には無定形炭素をどのように考え

* 分子科学研究所長 : 岡崎市明大寺西郷中 38
ていたかをみますと, やはりいろいろと研究されていた ことがわかります。黒鈆を硝酸のようなもので酸化する と黒鉛酸とよばれるあのになり,さらに酸化が進むとメ リット酸になります。乙れはベンゼン環の 6 個の水素の 代りに 6 個のカルボキシル基がついたものです。木炭な どを同じように酸化しても終局的にはメリット酸になり ます。それ故両者は似たようなあのであるとみなされま す。乙れは一つの化学的見方です。その時代の最初の重 要な進歩はX線回折法の出現です。1917 年Debye はは じめて無定形炭素のX線回折を試みました。その結果は 黒鉛亡あまり変わりがないととを見出したわけです。無 定形炭素の回折像には黒鉛の(002),(100),(110)に相 当する線が出ます。それらの線は幾分ぼんやりとしたい わゆるカーボン・パターンでありますが, 結晶粒子が小さ いことによるあのと一応解釈されます。乙の時代のとと として是非とも紹介したいのは日本の浅原源七博士の仕 事であります。同博士は 1922 年頃までにいろいろな種 類の炭素のX線回折を試みました。その当時のX線管球 は医者の使うあのができていました。カメラとしては手 作りの木製の箱で，前方にスリットがあり，まん中に試 料を执きその後方に写真乾板をおく仕掛けのあのでした。 同じ箱を 8 個つくり，X線管球のまわりにならべておき 6〜7 時間露出して像を得たといわれます。このような 装置で，実に，立派な，今日からみても変わらない観察 をされています。1922 年の理化学研究所報告第 1 巻に 発表されています。実は私はこの仕事を外国で出版され た本によって，はじめて知ったわけです。誠に恥ずかし い気がいたします。ついでながら浅原さんは日本の自動 車工業を育てた人の 1 人です。数年前に亡くなられまし たが，晚年は自動車工業会の会長を永くされた方です。 Hassel と Bernalが黒鉛結晶の構造をきめたのが 1924 年であります。そのあといろいろの研究がありますが省 略します。そして1940 年代になりますとWhite と Germer の電子線回折の報告が出ます。この Germerは電子線の 回折現象をはじめて見出した人です。電子線の回折像か らは 3 次元格子でなく 2 次元的格子構造であることがわ かります。私むその頃, 戦時中のことで情報の得がたい 時代でしたが, ススの電子線回折を行っていて同じこと に気付きました。同じ頃，BiscoeとWarrenの完全な X線回折の解析結果が報告されました。1942 年であり 
ます。それによれば，いわゆるカーボン・パターンは単 に結晶が小さくて回折効果がわるいためではなく, 乱層 構造によるあのであることを明らかにしました。炭素の 六角網平面の重なりかたの不整一面は互いに平行して 重なっているが， $a-, b$-軸に関しては規則性がないの で三次元の格子とはみなされない一によるもので， turbostratic structure よよばれることになりました。 また黒鉛のなかには通常の六方唱系の結晶のほかに三方 晶系の結晶があるととも同じ頃に見出されました。六方 晶系の結晶では隣り合った六角網平面の重なりかたは， $\mathrm{C}(00), \mathrm{C}\left(\frac{1}{3} \frac{2}{3}\right), \mathrm{C}(00)$ の関係でくり返されている が三方晶系の結晶では，C $(00), C\left(\frac{1}{3} \frac{2}{3}\right), C\left(\frac{2}{3} \frac{1}{3}\right)$, $\mathrm{C}(00)$ の関係に相当します。
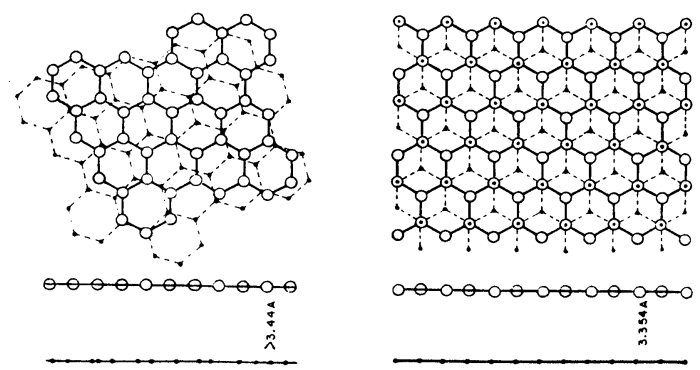

図 1 無定形炭素の乱層構造 (左) と黒鉛結晶(右)
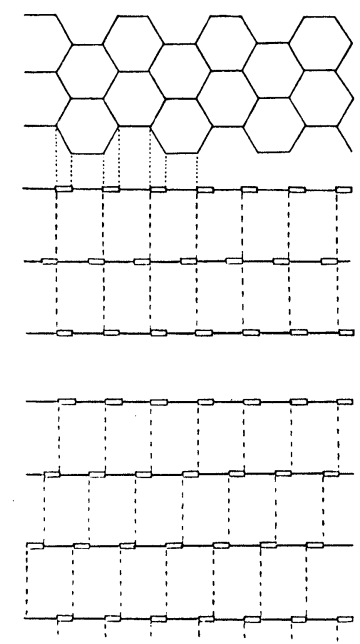

図2 六方晶系の黑鉛(上)と三方晶系の黒鉛(下)

以上のととを合せて考えると，いずれの場合む炭素の 六角網平面が基本となっていて，黒鉛では規則正しいつ み積なりで $a-, b$-軸ともにそろえている結果三次元格 子になっているが，無定形炭素では乱層構造となってい ます。扔そらく面と面とはvan der Waals 的な力で結 ばれているものと思われます。この考え方を扎し進める
と，炭素の六角網平面は一つの巨大な分子であるとみて よいと思われます。

てれから扔話することは，物質をみるのに二つの見方 があるということです。一つは物理的見方，他は化学的 な見方であります。この両者はどてがちがうかというと， 物理学では電子とか原子を単位としてその運動に基づい てものをみます。化学では分子を単位としてものをみま す。分子概念があとになっています。たとえば構造の乱 れについても物理学では原子の配列を基本とするのが普 通ですが化学では分子の配列についてみます。また化学 では機能ということをいいます。物理学者は余り使わな い。一番よく使うのは生物学者でしょう。私の研究所は 分子科学研究所ですが, 分子の構造とその機能に関する 研究を行うことになっています。機能というのは一つの 組織体があって，その組織に基づいて発現する性質や能 力を意味します。原子が集まって分子をつくるとき，そ の構造に基づいて生まれるあのとみるわけです。1940 年代から無定形炭素の研究が急速に進歩した理由の一つ は, 分子概念が導入されたためであると思います。炭素 の六角網平面は炭素原子の二次元的縮合体である分子に ほかならない。黒鉛では巨大な二次元分子ですが, 無定 形炭素の分子はその縮合度に応じていろいろあります。 それらは有機化合物であるとてろの縮合多環芳香族炭化 水素とみなされます。とのような観点から次の実験を 致しました。縮合多環芳香族化合物のなかには染料とし て合成されているものがあります。ビオラントロン， イ ソ・ビオラントロン拉よびピラントロンはその代表的な 例であります。これらの化合物はそれぞれ単斜晶系の結

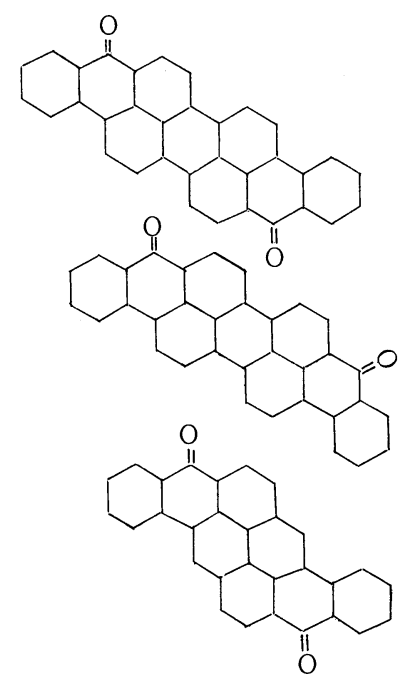

図 3 建染染料：上からイソ・ビオラントロン， ビオラントロン，ピラントロン 
晶で特有の色をあち染料として用いられるわけです。乙 の三つの染料を混ぜます。乙れらは濃硫酸にとけます が，それを水に入れると再び沈殿してその際に混晶とな ります。それは真黒な沈殿です。乙の混晶のX線回折像 は典型的なカーボン・パターンを示します。てれらの染 料の化学組成はそれぞれ次の通りで, 実は木炭などと余 り変りありません。 $400 〜 500^{\circ} \mathrm{C}$ で炭化した木炭に相当 します。

$\begin{array}{llrrr} & & \mathrm{C} \% & \mathrm{H} \% & \mathrm{O} \% \\ \text { ビオラントロン } & \left(\mathrm{C}_{34} \mathrm{H}_{16} \mathrm{O}_{2}\right) & 89.5 & 3.5 & 7.0 \\ \text { イソ・ビオラントロン } & \left(\mathrm{C}_{34} \mathrm{H}_{16} \mathrm{O}_{2}\right) & 89.5 & 3.5 & 7.0 \\ \text { ピラントロン } & \left(\mathrm{C}_{30} \mathrm{H}_{14} \mathrm{O}_{2}\right) & 88.7 & 3.5 & 7.9 \\ \text { 木炭 }\left(400^{\circ} \mathrm{C}\right) & & 82.7 & 3.8 & 13.5 \\ \text { 木炭 }\left(5000^{\circ} \mathrm{C}\right) & & 89.6 & 3.7 & 6.7\end{array}$

てのような試料を化学者に与えて，てれは何かと問えば 化学者は何上答えるでしょうか。化学分析とX線回折の 結果「炭素」であると答えることでしょう。てれが化学 的観点というものであります。この答えは正しいわけで す。私はこの実験の結果を, A New Suggestion for a Model Representing the Structure of Carbon Blackという報告として Journal of Colloid Science （1947）に投稿しました。乙の雑誌はその頃はじめてア メリカで創刊された雑誌です。また，まだ戦後のととで あり日本はアメリカの占領下でありましたから, アメリ 力軍の許可をむらって投稿したてとを拈ばえています。 このような事情ああって，ての論文は日本では余り読ん でくれた人がないようです。ただ一人フランスで Mering が大変ほめてくれたてとを人づてにききました。以来私 と Mering は互いに尊敬し合う仲になりました。このよ うなととをててに話す理由は，私としては，乙の実験を 契機としてものの見方, 化学的観点 (chemical aspect) ということを八ッキリとつかんだと思えたからでありま す。それは私自身のその後の研究の出発点となりました。 これらの化合物が炭素や黒鉛のモデルとなるのであれば, 逆に炭素や黒鉛にみられる物性が，乙れらの化合物にあ 期待されるはずである。そのような考えに従って縮合多 環化合物が半導体的性質をむつてとを見出したのであり ます。有機半導体の研究のいとぐちとなったわけであり ます。な打英国のUbbelohde むまたはやくから黒鉛を 芳香族炭化水素とみなしていたてとを知りました。

炭素材料の多面性が何に基づいて出てくるかというこ とは，化学的観点からみればやはり炭素原子の valence の特徵に求められます。炭素原子には 6 ケの電子があり ますが，化学結合にあずかる電子は $2 \mathrm{~s}(2), 2 \mathrm{p}(2)$ の 4 ケでありますが，ての電子は混成軌道をつくっていろ いろの結合の仕方をします。メタンやダイヤモンドにみ
られるのは tetragonal な $\mathrm{sp}^{3} ・$ 混成であります。エチレ ンやベンゼンにみられるのは trigonal な $\mathrm{sp}^{2}$ ・混成で, アセチレンでは digonalな sp・混成であります。てのうち 炭素に関係の深いのは $\mathrm{sp}^{2}$ ・混成で 3 ケの電子が trigonal な平面の軌道をつくります。残りの 1 ケの電子はて の平面に垂直な $\pi$ 軌道をつくります。ベンゼンでは 6 ケ の $\pi$ 電子があります。炭素の六角網平面はベンゼン環が 二次元格子に縮合したもので多数の $\pi$ 電子をむつてとに なります。共役系の $\pi$ 電子は動き易い特徴をむち，大き な網平面内ではあたかす金属の電子の如く動くことがで きます。炭素のいろいろの性質がこの可動性の電子に基 づくものと考えられます。一般に化学者が $\pi$ 電子に注目 するようになったのはやはり 1940 年代のととでありま す。極く最近ではアセチレンが線状に重合したポリアセ チレンの電気伝導性が注目されています。てれは一次元 の $\pi$ 電子共役系です。

炭素原子の原子価の特徵に基づいて無数の化合物がつ くられます。私は地球という天体は炭素という元素が化 合物をつくるのに最あ都合のよい条件をそなえているの であると思います。有機化合物というのは，元来は生物 体の組織をつくる化合物という意味でした。それは有機 的組織体の機能を担う化合物, 換言すれば，いろいろの 機能を生ずる可能性をむつ化合物であるわけです。炭素 原子の valenceの多様性に帰せられるものと思います。 最近では 2 価の炭素カルベンが注目をひいています。か つては有機化学反応の中間体として想像されていたすの ですが，今日では : $\mathrm{CH}_{2}$ ×チンの分子が認められてい るのみでなくその構造む正確に測られています。水の分 子に似て, $\mathrm{H}-\mathrm{C}-\mathrm{H}$ の原子価角は $103^{\circ}$ です(励起状態で は $136^{\circ}$ で三重項状態であるといわれます)。環状カルベ ンあ知られています。てれに関連して思い出されるてと があります。黒鉛は炭素の六角網平面からできています が，その端の炭素原子はどうなっているでしょうか。べ ンゼンのように水素がついているのでしょうか。それと あ酸素がついているのでしょうか。カーボンブラックや木 炭などでは水素や酸素がいろいろの形でついていてその 性格をきめています。1950年代のてとですが， valence の大家であった英国のCoulson（すでに故人）が，『自分 はか㸚が敉 2 価の炭素があって，黒鉛の網平面の端を 形成しているのではないかと思っているが，少々恥ず かしいのでてれまでだまっていた』ということを米国の Mrozowskiあての手紙にのべてあったてとをききました。 今日の環状カルベンに相当するわけです。しかし，ての 端がはたしてそうなっているのかどうかは判りません。 カーボンの ESRを測定しますと，何かわからないけれ どあスピンを満足しない吸収がみられます。カルベンの 
化学の立場から考えてみる必要があるかあしれません。

化学的なものの見方によれば,物理学ほどの厳密性に は欠けるかもしれませんが，あるアナロジーに従って大 局的な理解をすることができます。ベンゼン，ナフタレ ン，アントラセンというように芳香族炭化水素が大きく なると，その極限が黒鉛の巨大分子ですが，無定形炭素 類ではそれほど大きくはありません。X線回折法でみま すとベンゼン環の縮合は 10 個とか 20 個とか，せいぜい 100 個程度でしょう。芳香族炭化水素の分子とみなした 取り扱いが許されるでしょう。前にあ述べましたように 1940 年代は有機化合物の分子の電子状態に関する研究 が急速に進展した時代です。特に芳香族化合物の分子の 如き $\pi$ 電子系は，当時開拓された分子軌道法を適用する 最むよい例でありました。ここでは極く大ざっぱに申し ます。一般に電子の運動する状態を量子力学的にみます といくつものエネルギー・レベルで表わされます。その レベル間隔は電子の運動する空間の大きさに関係し, 空 間が大きいほどレベルとレベルの間隔はせまくなります。 芳香族化合物分子では $\pi$ 電子が分子面内で運動し，その 状態はいくつかの分子軌道で表わされます。ベンゼン環 の縮合した縮合多環芳香族炭化水素の分子では縮合環の 数がふえるに従って電子および $\pi$ 軌道の数がふえますが, 各軌道のエネルギー間隔は縮まってきます。電子で満さ れている結合性軌道とその上位にある空の反結合性軌道 との間隔も縮まってきます。分子が光を吸収して励起す るに要するエネルギーは小さくなります。縮合環の数 が増すに従って化合物 (染料)の色が深くなります。黒鉛 の分子はその極限に相当すると考えられます。無定形炭 素類加ら黒鉛に至る各段階で, 電気的性質をはじめとし ていろいろな物性の相異を縮合度とそれに基づく電子状 態のちがいとして解釈することができます。

結合性軌道の最上位のレベルから電子をとり出すに要

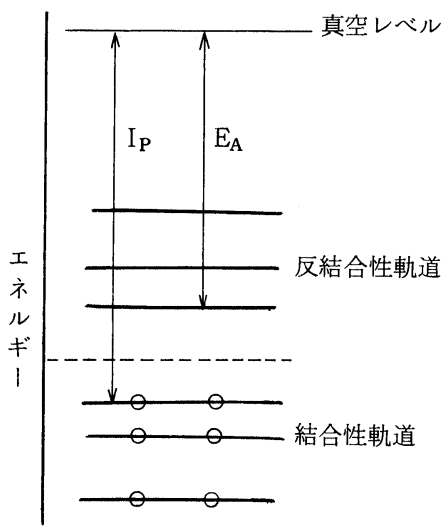

困 $4 \pi$ 電子軌道の例 (ベンゼン)
するエネルギーはイオン化ポテンシャル $\left(I_{\mathrm{P}}\right)$ に相当し ます。また反結合軌道の最下位のレベルに外から電子が 入るときに利得する仕事は電子親和力 $\left(\mathrm{E}_{\mathrm{A}}\right)$ で表わされ ます。イオン化ポテンシャルの小さい分子は陽性の分子 で，電子親和力は大きい程陰性の分子とみることができ ます。縮合多環芳香族炭化水素のイオン化ポテンシャル はその分子の形によってあ異なりますが，一般的にみて 縮合環の数がふえる程低くなります。ベンゼンでは 9.24 $\mathrm{eV}$ ，ナフタレンでは $8.15 \mathrm{eV} ，$ アントラセン $7.47 \mathrm{eV}$ ， ペリレン $7.00 \mathrm{eV}$ ，ビオラントレン $6.5 \mathrm{eV}$ な゙と測定さ れています。分子が集まって結晶になると，結晶からの イオン化ポテンシャルは $1.5 \mathrm{eV}$ 位低くなります。黒鉛の 結晶から電子をとり出すに要するエネルギ一は $4.7 \mathrm{eV}$ と いうことです。黒鉛の網平面分子のイオン化ポテンシャ ルは直接測ることができませんが，おそらく $5.9 \mathrm{eV} く$ いと推定されています。乙の值はアルカリ金属の原子の イオン化ポテンシャルに近い值です。電子親和力の值に ついては何むいわれていませんが，私は $3 \mathrm{eV} に$ 近い值 ではないかと想像します。乙れは八ロゲンの值に近い值 です。乙のような考えから黒鉛の巨大分子は陽性分子で あると同時に陰性分子とみなされます。黒鉛が臭素や硝 酸、濃硫酸などを吸収してコンプレックスを作るととは

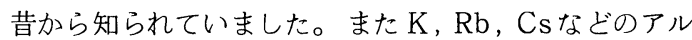
カリ金属の蒸気を吸収してコンプレックスをつくること あよく知られています。例えばカリウムの場合には， $\mathrm{C}_{8} \mathrm{~K}, \mathrm{C}_{24} \mathrm{~K}, \mathrm{C}_{36} \mathrm{~K}, \cdots な と ゙ の$ 化合物を形成します。 $\mathrm{C}_{8} \mathrm{~K}$ では赤味をおびた黄金色を呈し電気伝導性を増します。 セシウムとの化合物は超電導性を示すということです。 これらは一般に層間化合物とあよばれ，最近ではその物 性が注目されて詳しい研究が行われるようになりました。

話をはじめにあどして，化学的観点を導入したてとに より炭素材料の理解が著しく進んだ例としてはカーボン ブラックをあげることができるでしょう。人類にとって 最屯縁の深い炭素は木炭とススであります。ススは古く から墨汁として使用されました。今日であ完全に黒い染 料や顔料の合成はできません。カーボンブラックは依然 としてカラー用としての生命を保っています。しかしな んといってもゴムの強化材としての用途が最大なととは いうまであありません。また戦争の話になりますが，戦 争がはじまった当時, つまり 1940 年代には日本では夕 イヤに使用できるようなカーボンブラックはありません でした。アメリカからの輸入品でした。カーボンブラッ クの製造を強化すると同時に改良をしなければならなか ったわけです。カーボンブラックがゴムを強くする機構 はなかなかわからなかったのです。今はどの位までわか るようになっているのか正直な所私は存じません。しか 
しカーボンブラックの研究はそもそも炭素とは何かとい うことから始まりました。

カーボンブラックに関しては, むう一つの思出があり ます。戦争中B-29 というアメリカの爆撃機がとんでき て爆弾を落していきました。これを撃墜すると，機体の なかにいろいろの複雑な電気回路や装置があって，その なかから今日広く使われているソリッドオーム抵抗体が みつかったのです。この小さい物体が沢山使用されてい るわけですが, その中味の一つがカーボンブラックで す。戦後になって, ソリッドオームは国産化されたわけ ですが，それには相当な苦労がありました。一定の抵抗 值を出すのがむずかしく，ぶどまりが大変悪い次第で す。

電子顕微鏡の出現は全く新しい視野を開きました。力 一ボンブラックが一つ一つ丸い球からできている写真を 見たよきは大きな驚きでありました。この驚きは私だけ ではなかったはずです。一つの例を申します。すでに故 人である中谷宇吉郎博士はその随筆などにあみられるよ うに視野の広い物理学者でした。その中谷さんが, 墨汁 の電子顕微鏡写真を岩波の「科学」に投稿して，『自分
はかねてより墨の色に興味をもっているが, 良い墨汁で はスミは丸い球状である。乙れとそ墨汁の良し悪しをき めるあのであろう』，私の記憶では大体てんな主旨のてと を言われていたように思います。実はススの粒子は皆丸 いのです。しかしカーボンブラックの性格を評価するに あたっては，電子顕微鏡でみられる粒子の大きさ，その 集合状態(ストラクチャーとよばれる)が大切な要素であ ることはいうまであありません。さらにこの粒子を構成 している結晶子の大きさ，それは乱層構造をしています が，それによって縮合多環体としての分子の大きさが想 定されます。その上でこの分子の網平面の端には，どん な化学結合状態があるのか, 水酸基やカルボキシル基や さらにはケトン構造, ラクトン構造などの存在の可能性 が有機化学的観点から検討されるようになりました。

日本学術振興会第117 委員会の活動が活発に行われる ようになったのも1940年代の後期でした。その結果昭和 24 年(1949 年)に『炭素』の刊行をみるに至りました。

本稿は去る 2 月 22 日炭素材料学会ゼミナーで行った 講演の記録に基づくあのであるが，本誌 100 号記念に添 うように表題の如く内容をとりまとめたあのである。

\section{記 事}

\section{学振第 117 委員会第157 回会議}

学振第 117 委員会第 157 回会議が昭和 54 年 11 月 27 日 (火) 豊橋技術科学大学大会議室において開催された。 A，B，C各分科会に下記の資料が提出され，活発な討論 がなされた。

117-157-A-1 炭素試料の組織 (texture), 形状と5 kbar下での黒鉛化性との関連についての一考察

（三重大工）神谷寛一ほか

117-157-A-2 ビフェニレンの加熱変化

（群大工）大谷杉郎ほか

117-157-B-1 生石油コークスを原料とする異方性黒 鉛材料の試作普石油化学) 槌谷正俊ほか 117-157-B-2 高炉用炭素材の水蒸気との反応性
（横浜国大）鳥飼直親ほ加

117-157-B-3 気相成長炭素繊維の耐熱性

（信大工）遠藤守信ほか

117-157-C-1 極限粘度より求めた分別ピッチの分子 形状及びサイズ（豊橋技科大）逆井基次ほか 117-157-C-2 Anisotropic Electrical Conduction in Relation to the Stacking Disorder in Graphite (別刷) (日大理工) 都竹卓郎

117-157-C-3 炭素繊維中のマイクロボイドの形状と 大きさの分布を半定量的に表わす方法

（金材研）富塚 功ほ加 